\title{
SOCIAL STUDIES TEACHERS' PEDAGOGICAL CONTENT KNOWLEDGE AND ITS INFLUENCE ON THEIR ASSESSMENT PRACTICES IN JUNIOR HIGH SCHOOLS IN THE WEST AKIM MUNICIPALITY, GHANA
}

\author{
Robert Andrews Ghanney ${ }^{1 \mathrm{i}}$, \\ Edward Boafo Agyei ${ }^{2}$ \\ Department of Basic Education, \\ University of Education, Winneba, \\ Ghana
}

\begin{abstract}
:
The study examined Social Studies teachers' pedagogical content knowledge and its influence on their assessment practices in Junior High Schools in the West Akim Municipality in the Eastern Region of Ghana. The study was hinged on the Pedagogical Content Knowledge (PCK) model by Shulman, (1986) and adopted the concurrent triangulation design with mixed methods approach. The census and convenience sampling techniques were used to select seventy-seven (77) and ten (10) respondents respectively for the study. Questionnaire, observation check list and document analysis were used by the researchers as instruments for data collection. These instruments were used to enable the researchers triangulate the information to test the consistency of the findings. A reliability analysis using Cronbach's Alpha was performed to determine the internal consistency of each construct in the questionnaire and the observation checklist. The data obtained from the three instruments were analysed using descriptive statistics (frequency counts, percentages, mean and standard deviation). Inferential statistics (Pearson Product Moment Correlation) was used to test the stated hypothesis. The results indicated that generally, most of the JHS Social Studies teachers possessed some level of pedagogical content knowledge. Again, Social Studies teachers practice traditional assessment method (pen/pencil and paper). The results further pointed out that pedagogical content knowledge influence teachers' assessment practices $\left(r=.819^{* *}\right.$, sig. $=.000^{* *} \mathrm{p}<0.05, \mathrm{CI}=95 \%, \mathrm{n}=77,2$-tailed). It is recommended that Social Studies teachers within the West Akim Municipality should make use of alternative assessment techniques as these other techniques will help cater for affective and psychomotor assessments which will help develop pupils' attitudes and values.
\end{abstract}

${ }^{i}$ Correspondence: email ghanney66@yahoo.com 
Keywords: social studies teachers, pedagogical content knowledge, assessment practices, junior high schools

\section{Introduction}

Education for citizenship has become a major concern and the focus of primary, secondary and the early education curriculum across the globe (Akhtar, 2008). "It is seen as the fulcrum on which the development of relevant knowledge, skills, values and understanding required to become informed, active and responsible citizens should revolve" (Eshun, Naya, Brew \& Bordoh, 2019, p. 210). This, therefore, goes to say that learners need a unique and peculiar type of education which will enable them to participate effectively in life. National Council for Social Studies (NCSS) (2001), expatiated that if a nation is to completely grow its citizens' readiness to follow its democratic values, it must help progress towards achieving the dream of effective teaching and learning in Social Studies. This means, Social Studies as Citizenship Education is the study aimed at inculcating desirable skills, attitudes, values and relevant knowledge among learners to enable them to participate effectively in the civic life of their communities

Ultimately, Social Studies is or should be, about helping students develop positive values that will lead them to make good decisions, do the right thing, be decent, moral, caring, and involved citizens. The praiseworthy aims of Social Studies in making students informed, problem solvers, good decision-makers and cultivating attitudes suited to productive citizenship in an interdependent democratic society cannot be accomplished without appropriate and efficient subject teaching. Tantrarungroj \& Suwannatthachote (2012) posit that teacher education is designed basically to equip student teachers with the pedagogical content knowledge (PCK), skills and attitudes that are required for classroom teaching. They further cited Koehler and Mishra (2008) and Shulman (1986) who had earlier argued that every teacher is expected to possess teaching expertise that is derived from a combination of content knowledge and pedagogical knowledge.

Effective teaching of Social Studies requires that teachers of the subject hold perceptions that fall in line with what the subject is intended for. This implies that knowledge of Social Studies for teaching goes beyond what is stipulated in the Social Studies curriculum content, but also pedagogy plus content knowledge will lead to effective Social Studies teaching that will ultimately imbibe the attitudes, values and skills of the students for their survival in society. If the popular values of Social Studies are to be understood, the availability of high-quality Social Studies teachers in sufficient numbers is a sine qua non if the prominent ideas of the Social Studies curriculum are to be realised.

Pedagogical content knowledge (PCK) represents the blending of content and pedagogy into an understanding of how particular topics, problems, or issues are organised, represented and adapted to the diverse interests and abilities of learners, and presented for instruction (Shulman, 1987; Nind, 2020). It included the "most useful forms of representation of these ideas, the most powerful analogies, illustrations, examples, explanations 
and demonstrations in a word, the ways of representing and formulating the subject that make it comprehensible to others" (Shulman, 1987, p. 9). PCK involves knowing what teaching approaches fit the content and likewise, knowing how elements of the content can be arranged for better teaching. This knowledge is different from the knowledge of a disciplinary expert and also from the general pedagogical knowledge shared by teachers across disciplines. Shulman (1987) furthermore stated that PCK is a type of knowledge that is unique to teachers and in fact what teaching is about. It concerns the manner in which teachers relate their pedagogical knowledge (what they know about teaching) to their subject matter knowledge (what they know about what they teach), in the school context, for the teaching of specific pupils. It is the integration or the synthesis of teachers' pedagogical knowledge and their subject matter knowledge that comprises pedagogical content knowledge. For example, an experienced science teacher's knowledge of science is structured from a teaching perspective and is used as a basis for helping students to understand specific concepts.

The researchers extended Shulman's theory by applying it to the phenomenon of teachers incorporating material for successful teaching into their pedagogy. It is necessary to know that the knowledge of the teachers (CK and PK) which, if well integrated, will influence the classroom practice of the teachers and in effect aid in the attainment of the Social Studies aims and purposes. Shulman's hypothesis discussed above indicates that teachers of varying levels of form of expertise have two distinct calibres in Social Studies. Some may possess only one of Shulman's proposed two types of knowledge. However, a teacher who possesses only one of the two knowledge is insufficient in achieving our desired aim of producing citizens who are assets rather than liabilities to society. Thus, for teachers to teach and assess students holistically, they must possess all two types of knowledge emphasised in Shulman's theoretical framework (PCK) which this current study adopts.

Effective teachers, according to Parkay and Stanford (2014), use a variety of teaching techniques and assessments approaches depending on their circumstances and on the goals and objectives they wish to achieve. This indicates that there is a need for constructive assessment to meet the Social Studies goals. Assessment is a dynamic process and should be based on the objectives which were clearly selected from the taught content. Using effective and varied assessments increases the students' potential and cognitive skills. Assessment is a key component of teaching and learning and involves systematic process of data gathering about students' progress. Phye (2007) described assessment as the organised process of gathering and synthesising information relating to the intent of finding and recording the strengths and weaknesses of pupils, preparing and optimising instruction or process evaluation and making decisions about pupils and the process, tools and methods used to gather information.

To buttress Phye definition, Hammil (1987) defined assessment as "the act of acquiring and analysing information about students" (p.5). Hammil (1987) notes that the information gathered about the pupils requires awareness of the personal attributes, cognitive abilities and academic achievement of an individual. In the process of obtaining 
information about the pupils, devices such as observation, performance ratings, paper and pencil tests are used to obtain information about learning for the pupils. The information collected allows teachers to make value judgment that includes the pupil's learning progress (Linn \& Gronlund, 1995). The primary aim of assessment is to foster learning of worthwhile academic content for all pupils. Education reformers believe that assessment and instruction are two sides of a coin and that an intangible cord connects assessment, education and teaching in the learning process (Kathy, 2000). Assessment is required not only to take care of the knowledge and understanding of pupils, but also to assess abilities, increase in training, review, synthesis and establish positive attitudes. Noori (as cited in Odetoyinbo, 2004) on the contrary stated that for years, tests have been designed to reflect the positivistic-quantitative paradigm and have been developed to ensure that measurement of student achievement was aimed primarily at assessing cognitive habits such as comprehension, understanding and other thinking skills that are typically gained after exposure to some learning experiences and knowledge of subject matter.

Concerns are being raised about the challenge for the Social Studies teacher on how to use pedagogical content knowledge (PCK) in ways that will increase content understanding and prepare students who are needed to shape the future and ensure the welfare of the local, national and global community. Indeed, teachers themselves report that pedagogical content knowledge is the core content of a teacher's knowledge. Therefore, lack of teacher knowledge about a topic should not be taken lightly.

One aspect of teaching which is key to the realisation of Social Studies goals is assessment. While it serves various purposes, its core function is to support and enhance student learning (Rust, 2002). The profile dimensions in the Junior High School Social Studies curriculum places more emphasis on the development of the right attitudes and values (Ministry of Education, 2007). However, this has not been the case in West Akim Municipal in the face of growing negative behaviour by students in the school. The problem seems to be lack of knowledge especially about the goals of Social Studies by some teachers in the classroom. This is affirmed by (Danielson, 2007) who asserts that a teacher cannot teach what he or she does not know. Kahan, Cooper \& Betha (2003) review expressed a similar concern that students learn more Social Studies if their teachers knew more Social Studies. This worrying situation has triggered a lot of research mostly on the knowledge (pedagogical and content knowledge) of the teacher (Voogt, Fisser, Roblin, Tonder \& Van-Braak, 2012). It appears little research has been carried out on how the knowledge (pedagogical and content knowledge) of the teacher influences how teachers assess their pupils in Social Studies despite the argument by Ernest, (1991) that teachers' classroom practices are related to their knowledge of the subject matter (content) and of teaching (pedagogy). Akim municipality is no exception.

Bordoh, Eshun, Kofie, Bassaw, \& Kwarteng (2015) conducted a study on Social Studies teachers' content knowledge in Senior High Schools in the Sekondi-Takoradi Metropolis in the Western Region of Ghana which revealed that, many of those Social Studies teachers who teach the subject at the Senior High School in the Sekondi-Takoradi 
Metropolis have inadequate content knowledge in Social Studies. This made them largely unable to understand the essence of the problem in the syllabus. Social Studies teachers therefore did not select facts, which will develop the civic competences of the learners. These findings suggest that many Social Studies teachers who teach the subject at the Senior High School lack the requisite knowledge to teach the subject. Quashigah, Eshun \& Mensah (2013) have taken a step towards discovering how the knowledge of the teacher influences their assessment practices. They however focused on how the pedagogical content knowledge of the teacher influenced their crafting of test items at the Senior High School. All these studies were conducted at Senior High School leaving a doubt as to the situation at the basic level.

Assessing learners holistically means, assessing the learners in all the learning domains. That is cognitive, affective and the psychomotor. This has not been the case in the West Akim Municipality as our personal observation and interaction show clearly that, Social Studies teachers at the junior high school (JHS) had a casual approach to teaching and assessment. That is, some teachers teach and set tests items that would only address one level of the taxonomy of educational objectives while others would duplicate items from past examination papers. Also, test items appear poorly structured and their assessments procedures lacked variety. The concerns are; what is the PCK of Social Studies teacher? What are the assessment practices of Social Studies teachers? And, to what extent does the knowledge of the Social Studies teacher influence their assessment practice in the classroom at Junior High Schools in the West Akim Municipality.

The findings of the study would help the Directors of the Ghana Education Services (GES) and Social Studies curriculum specialists/experts to organise training programmes such as in-service training, seminars, workshop and professional courses for Social Studies teachers on regular basis so that they would be abreast with modern content knowledge and pedagogical knowledge for the teaching and learning of the subject Social Studies. Also, National Social Studies Teachers Association (NaSSA) would use the findings of this study to help improve upon its members' pedagogical content knowledge and their means of assessing students in the subject in order to reflect the nature, purpose and objectives of the subject.

The following research questions were formulated to guide the study.

1) What is the pedagogical content knowledge of Social Studies teachers at the Junior High School level in the West Akim Municipality?

2) What are the assessment practices of Junior High School Social Studies teachers in the West Akim Municipality?

The following hypothesis was formulated to guide the conduct of the study.

$\mathrm{H}_{0}$ : There is no statistically significant relationship between the pedagogical content knowledge of Social Studies teachers and their assessment practices at the Junior High School level in the West Akim Municipality.

$\mathbf{H}_{1}$ : There is a statistically significant relationship between the pedagogical content knowledge of Social Studies teachers and their assessment practices at the Junior High School level in the West Akim Municipality. 


\section{Methodology}

This study was aligned to the pragmatist research philosophy. Gray (2013) argues that, in order to make research meaningful and legitimate, research conducted within the pragmatist framework is free to use the methodology of qualitative as well as quantitative paradigms. This paradigm accepts a mixture of ontology and epistemology (Wahyuni, 2012). The study adopted the concurrent triangulation design within the mixed method approach. Creswell (2009) argues that, in this design, a researcher collects both quantitative and qualitative data, analyzes them separately, and then compares the result to see if the findings confirm or disconfirm each other. In this case, the quantitative and qualitative data collection are concurrent, happening during one phase of the research study.

The West Akim Municipality has a total number of sixteen (16) private JHS and forty-six (46) public JHS with seventy-seven (77) Social Studies teachers for the 2019/2020 academic year. In this study, the target population comprised all Social Studies teachers teaching the subject in both public and private Junior High School (JHS) in the West Akim Municipality. The justification for this population is their relatedness or significance to the problem identified. Hence, their views were crucial in gaining an understanding of the variables.

According to Cohen (2000) estimating sample size differ based on the statistical tool employed by the researcher. He further opines that, in correlational analysis, sample size can range from a minimum of eighty-five (85) to a maximum of one hundred and twenty (120). Based on the above assertions, the researchers used all the seventy-seven (77) Social Studies teachers within the West Akim Municipality. This makes the sampling census in nature. Census was employed because large sample size gives better judgement over smaller one, provided such sample are available and can be accessed.

Boyd (2001) is of the opinion that, two to ten participants were sufficient to reach saturation in qualitative study. In order to obtain first-hand information on the pedagogical content knowledge as well as the assessment practices of Social Studies teachers, the researchers conveniently selected and observed ten (10) teachers out of the seventy-seven (77) sample size. Again, the ten (10) teachers observed were asked to submit questions they have designed and used for class exercises and class test.

Denzin \& Lincoln (2000, p.5) stated, "The use of multiple methods or triangulation reflects an attempt to secure an in-depth understanding of the phenomenon in question. It adds rigor, breadth, complexity and richness to an inquiry". "The trustworthiness of the conclusions established by triangulation was superior because they had been verified through the use of multiple data sources" (Gay, Mills \& Airasian, 2009, p. 88). A set of structured questionnaire items were drafted in line with the research questions and administered to respondents. The questionnaire was in three sections (A, B, and C). section A covered the personal information (demographic data) of respondents. These include, name of the school, sex of the teacher, teachers' educational qualification and the number of years teachers have taught Social Studies. Section B focused on the pedagogical content knowledge of Social 
Studies teachers with Section $C$ on the assessment practices of Social Studies teachers. Questionnaire for Section B to Section C were adapted from Schmidt, Baran, Thompson, Mishra, Koehler\& Shin (2009), Bordoh et al. (2015), Eshun et al. (2013). Items on the questionnaire were on a five-point Likert-scale. Numerical weights that were assigned to the scales are:1 - Strongly Disagree, 2 - Disagree, 3 -Undecided, 4 - Agree and 5 Strongly Agree. Questionnaire was used because the respondents are teachers and they can read and write. Again, the questionnaire was able to keep respondents on the subject. Additionally, questionnaire afforded the researchers the opportunity to elicit the opinions of a wide range of respondents. Again, questionnaire was used because it ensured the standardization of the data elicited from the respondents. The Questionnaire also helped in the quantitative analysis of the data obtained.

Observation checklist was prepared and used to cross check the questions asked in the questionnaire on Social Studies teachers' pedagogical content knowledge and their assessment practices. Observation was used because, the technique provided the researchers the opportunity to witness how the teaching of Social Studies is done in schools in the study area. In this way, observation becomes an effective means of reporting precisely what prevails about the phenomenon under study with greater reliability. An observation checklist for content knowledge was adapted from Bordoh et al. (2015).

Like other analytical methods in qualitative research, document analysis requires that data be examined and interpreted in order to elicit meaning, gain understanding and develop empirical knowledge (Corbin \& Strauss, 2008). Schram (2003) identifies advantages of using document analysis. Firstly, documents can be accessed at a time convenient to the researcher at a minimum cost. Secondly documents tend to contain data that are thoughtful because adequate time and care is given to compile them. In spite of this the researchers were contented with the limitations associated with document analysis. Specifically, the researchers collected documents that consisted of students' classroom assessment records such as exercises and class test from Social Studies teachers. These data were very essential for this study because they helped the researchers ascertain the domain of educational objectives that Social Studies teachers in the West Akim Municipality assessment tasks emphasised. The researchers collected Students' assessments records from ten (10) Social Studies teachers.

The validity of the questionnaire, particularly the face and content validity were established by senior colleague supervisors. This was done by constructing the items in line with the research questions and subjected to scrutiny. According to Archambault \& Crippen (2009) having experts who reviewed novice researchers' instruments to ensure that items were complete, relevant and arranged in appropriate format will yield a high level of face and content validity. Similarly, the observation check list went through the same filtering process as the questionnaire. In order to establish the reliability of the questionnaire and the observation checklist, the researchers pilot tested the questionnaire and the observation checklist among thirty (30) and ten (10) Social Studies teachers respectively. These Social Studies teachers were selected from Junior High School within 
the Upper West Akim District in the Eastern Region of Ghana because the district has similar characteristics in terms of geographical area and training as respondents from the Lower West Akim Municipality.

A reliability analysis using Cronbach's Alpha was performed to determine the internal consistency of each construct in the questionnaire and the observation checklist. These are listed in Table 1.

Table 1: Reliability Test Results of the Measured Variables

\begin{tabular}{|l|c|c|}
\hline Constructs & $\begin{array}{c}\text { Number of Items } \\
(\mathbf{Q} / \mathbf{O})\end{array}$ & $\begin{array}{c}\text { Reliability Value } \\
(\mathbf{Q} / \mathbf{O})\end{array}$ \\
\hline Content Knowledge (CK) & $\mathrm{r}=13 / 04$ & $\mathrm{r}=0.834 / 0.692$ \\
\hline Pedagogical Knowledge (PK) & $\mathrm{r}=07 / 06$ & $\mathrm{r}=0.845 / 0.712$ \\
\hline Pedagogical Content Knowledge (PCK) & $\mathrm{r}=07 / 05$ & $\mathrm{r}=0.765 / 0.672$ \\
\hline Assessment Practices (AP) & $\mathrm{r}=15 / 09$ & $\mathrm{r}=0.725 / 0.719$ \\
\hline \multicolumn{2}{|l}{ Key: $\mathrm{Q}=$ Questionnaires; $\mathrm{O}=$ Observation $\mathrm{r}=$ Reliability co-efficient } \\
\hline
\end{tabular}

Source: Field Data (2020).

According to De Vellis (1991) and Fraenkel \& Wallen (2003) a reliability value within 0.6 to 0.9 is considered highly reliability. Hence the various items in each construct had the potential of eliciting the desired information

To reach the respondents for the main data collection, introductory letters were collected from the Head of Basic Education Department of the University of Education, Winneba which was used to obtain permission from the municipal Director of Education of the Lower West Akim Municipality and the Head teachers of the selected schools for the administration of the instruments. This enabled the study to get the needed attention, support and co-operation from the respondents. The researchers held a formal discussion with sampled school authorities and teachers to schedule a date for the administration of the questionnaires. After getting the permission, the researchers explained the questionnaire items to the respondents in order to elicit accurate information from the respondents. A total of seventy-seven (77) questionnaires was administered to the respondents personally by the researchers and again collected from them by the same researchers. The respondents were given some days to respond to the questionnaire, but some responded and handed them over the same day. The overall response rate of the questionnaire was $100 \%$. The researchers again scheduled a day with the teachers selected for the observation. Each teacher was observed twice and each of the lessons that was observed lasted for seventy (70) minutes. For convenience and ethical considerations, the study was guided by research code of ethics such as informed consent, anonymity and confidentiality of the respondents when collecting primary data. Secondary information from books, journals, newspapers and online which served as relevant literature for the study were duly acknowledged.

The quantitative data entry and analysis was done using the Statistical Product for Service Solution (SPSS) software version 25. The researchers used descriptive statistics (frequency counts and percentages, mean and standard deviation) to analyse all the 
research questions. Responses from the observational checklist was analysed using mean and standard deviation. Also results from the document analysis were analysed using frequency counts and percentages. Inferential statistics, specifically, Pearson Product Moment Correlation was used to test the stated hypothesis. The results were tabulated and interpreted to draw sound findings and conclusions.

Table 2: Demographic Characteristics of the Respondents $(n=77)$

\begin{tabular}{|l|l|c|c|}
\hline Variables & Subscale & Freq. & Percent \% \\
\hline \multirow{2}{*}{$\begin{array}{l}\text { Staff } \\
\text { Gender }\end{array}$} & Male & 48 & 62.3 \\
\cline { 2 - 4 } $\begin{array}{l}\text { Current } \\
\text { Educational } \\
\text { Qualification }\end{array}$ & Female & 29 & 37.7 \\
\cline { 2 - 4 } & SSSCE/WASSCE & 04 & 5.2 \\
\cline { 2 - 4 } & Cert “A" & 02 & 2.6 \\
\cline { 2 - 4 } & Diploma & 55 & 71.4 \\
\cline { 2 - 4 } & 1st Degree & 15 & 19.5 \\
\cline { 2 - 4 } & Master's Degree & 01 & 1.3 \\
\hline
\end{tabular}

Source: Field Data (2020).

Data in Table 2 show results on the demographic characteristics of the Junior High School Social Studies teachers in the West Akim Municipality in the Eastern Region of Ghana. The results indicate that majority of the teachers were males $(n=48,62.3 \%)$. The females were less represented $(n=29,37.7 \%)$. With respect to the current educational qualification, the results show that the teachers with Diploma were the majority $(n=55,71.4 \%)$. Those with a first degree followed $(n=15,19.5 \%)$. Also, teachers that were found to teach with SSSCE/WASSCE certificate were 4 representing 5.2\%. In addition, those found teaching with cert " $\mathrm{A}$ " were 2 representing $2.6 \%$. Those with a master's degree were the least represented $(\mathrm{n}=01,1.3 \%)$.

\section{Result and Discussion}

Research Question One: What is the pedagogical content knowledge of Social Studies teachers at the Junior High School level in the West Akim Municipality?

For effective teaching, Harris, Mishra \& Koehler, (2009) maintain that knowledge of teaching and learning, assessment procedures, awareness of pupils' prior knowledge and content-related misconceptions are very essential. Thus, the acquisition of only CK is as useless as content-free skills (Shulman, 1986). This means that teachers' possession of content knowledge without the skills that will make it comprehensible to students renders it without value in the teaching and learning process. Inferring from this, the researchers were motivated to gather scientific evidence with respect to the PCK of Social Studies teachers at the Junior High School level in the West Akim Municipality. The ensued evidences are presented in Table 3. 
Table 3: Descriptive Statistics of Pedagogical

Content Knowledge of Social Studies Teachers ( $\mathrm{n}=77)$

\begin{tabular}{|c|c|c|c|c|c|c|c|c|}
\hline \multirow{3}{*}{$\begin{array}{l}\text { Items on Pedagogical } \\
\text { Content Knowledge (PCK) }\end{array}$} & $\mathbf{M}$ & SD & Min. & Max. & \multicolumn{2}{|c|}{ Kurtosis } & \multirow{2}{*}{ MR } & \multirow{2}{*}{ Remarks } \\
\hline & Stat. & Stat. & Stat. & Stat. & Stat. & Std. E & & \\
\hline & \multicolumn{8}{|c|}{ Criterion/Test Value $=\mathbf{2 . 5 0}$} \\
\hline $\begin{array}{l}\text { I can present the content of Social } \\
\text { Studies to the diverse interest and } \\
\text { abilities of pupils. }\end{array}$ & 3.66 & .372 & 1.00 & 4.00 & .505 & .424 & 1st & HPCK \\
\hline $\begin{array}{l}\text { I can effectively integrate the content, } \\
\text { method and the characteristics of } \\
\text { learners. }\end{array}$ & 3.52 & .293 & 1.00 & 4.00 & .343 & .861 & 2nd & HPCK \\
\hline $\begin{array}{l}\text { I display expectation of possible } \\
\text { difficulties pupils may face during } \\
\text { instruction and address them. }\end{array}$ & 3.47 & .328 & 1.00 & 4.00 & .348 & .354 & $3 \mathrm{rd}$ & HPCK \\
\hline $\begin{array}{l}\text { I can represent and formulate the Social } \\
\text { Studies content that make it } \\
\text { comprehensible to others. }\end{array}$ & 3.42 & .534 & 1.00 & 4.00 & .336 & .348 & 4 th & HPCK \\
\hline $\begin{array}{l}\text { I can use drill and practice as a teaching } \\
\text { strategy to enable pupils memorize } \\
\text { concept and historical aspect of Social } \\
\text { Studies. }\end{array}$ & 3.41 & .345 & 1.00 & 4.00 & .395 & .304 & 5 th & HPCK \\
\hline $\begin{array}{l}\text { I have techniques in assessing pupils' } \\
\text { understanding of content taught. }\end{array}$ & 3.36 & .298 & 1.00 & 4.00 & .292 & .444 & 6th & HPCK \\
\hline $\begin{array}{l}\text { I possess the philosophy of the subject } \\
\text { Social Studies and learning of pupils. }\end{array}$ & 3.29 & .229 & 1.00 & 4.00 & .453 & .393 & 7 th & HPCK \\
\hline Means of means / SD & 3.48 & .342 & & & & & & \\
\hline
\end{tabular}

Source: Field Data (2020)

As portrayed in Table 3, seven (7) items were constructed to measure the pedagogical content knowledge (PCK) of Social Studies Teachers. Reading from Table 3, the kurtosis values results were within the acceptable limit for normal distribution of \pm 2 (George \& Mallery, 2011) demonstrating that the data were normal (not skewed to either positive or negative). This implies that the data did not violate the normality assumption and as such, using the descriptive statistics was justifiable. From Table 3, it was evident that most teachers can present the content of Social Studies to the diverse interest and abilities of pupils $(\mathrm{M}=3.66, \mathrm{SD}=.372, \mathrm{KS}=.505$, Std. $\mathrm{E}=.424, \mathrm{n}=77)$. Similarly, it was found that majority of the teachers can effectively integrate the content, method and the characteristics of learners $(\mathrm{M}=3.52, \mathrm{SD}=.293, \mathrm{KS}=.343$, Std. $\mathrm{E}=.861, \mathrm{n}=77)$. This manifest shows the teachers have enough understanding in pedagogical content knowledge in Social Studies.

The Social Studies teachers further confirmed that they display expectation of possible difficulties pupils may face during instruction and address them. This was established after the mean and standard deviation of $(\mathrm{M}=3.47, \mathrm{SD}=.328, \mathrm{KS}=.348, \mathrm{Std} . \mathrm{E}=$ $.354, n=77$ ) was realised from their responses. It was further asserted that majority of the 
teachers can represent and formulate the Social Studies content that make it comprehensible to others $(\mathrm{M}=3.42, \mathrm{SD}=.534, \mathrm{KS}=.336$, Std. $\mathrm{E}=.348, \mathrm{n}=77)$. Majority of the respondents agreed to the statement that they can use drill and practice as a teaching strategy to enable pupils memorize concept and historical aspect of Social Studies $(\mathrm{M}=3.41, \mathrm{SD}=.345, \mathrm{KS}=.395$, Std. $\mathrm{E}=.304, \mathrm{n}=77)$. This portrays how the teachers can sufficiently blend content and pedagogy to aid pupils understanding of Social Studies concept. It was again found that most teachers have techniques in assessing pupils' understanding of content taught $(\mathrm{M}=3.36, \mathrm{SD}=.298, \mathrm{KS}=.292$, Std. $\mathrm{E}=.444, \mathrm{n}=77)$. Finally, it was revealed that most of the teachers possess the philosophy of the subject Social Studies and learning of pupils $(\mathrm{M}=3.29, \mathrm{SD}=.229, \mathrm{KS}=.453$, Std. $\mathrm{E}=.393, \mathrm{n}=77)$. This very finding affirms the view of Quartey (2011) that Social Studies teachers need to possess the philosophy of the subject they teach and learning of pupils. The philosophy provides guidance and direction in choosing content, objectives, teaching and learning experience and nature of assessment. The overall mean of means and standard deviation result of teachers' self-reported data $(\mathrm{M}=3.48 ; \mathrm{SD}=.342)$ suggested that Social Studies teachers' level of PCK is high and as such they can effectively organize, interpret and integrate content and pedagogy in order to deal with myths and difficulties that students experience when learning a specific content in Social Studies.

\subsection{Observation Results of (PCK)}

Table 4: Observation Checklist Results on Pedagogical Content Knowledge $(n=77)$

\begin{tabular}{|l|c|c|c|c|}
\hline Statement & M & SD & Rank & Remarks \\
\hline $\begin{array}{l}\text { Teacher effectively blends pedagogy and } \\
\text { content during teaching. }\end{array}$ & 3.24 & .263 & 1 st & $\begin{array}{c}\text { Very } \\
\text { Competent }\end{array}$ \\
\hline $\begin{array}{l}\text { Teacher uses real life examples and analogies to } \\
\text { present the content of Social Studies to the diverse } \\
\text { interest and ability of pupils. }\end{array}$ & 3.11 & .234 & 2 nd & $\begin{array}{c}\text { Very } \\
\text { Competent }\end{array}$ \\
\hline $\begin{array}{l}\text { Teacher demonstrates effective use of content } \\
\text { and pedagogy knowledge during teaching. }\end{array}$ & 3.07 & .343 & 3 rd & $\begin{array}{c}\text { Very } \\
\text { Competent }\end{array}$ \\
\hline $\begin{array}{l}\text { Teacher addresses pupils' difficulties they face } \\
\text { during instruction by representing and formulating } \\
\text { the content that makes it comprehensible. }\end{array}$ & 3.03 & .233 & 4 th & $\begin{array}{c}\text { Very } \\
\text { Competent }\end{array}$ \\
\hline $\begin{array}{l}\text { Teacher uses different assessment techniques } \\
\text { in assessing pupils' understanding of content taught. }\end{array}$ & 2.56 & .924 & 5 th & Competent \\
\hline Means of means/SD & 3.05 & .399 & & \\
\hline
\end{tabular}

Source: Field Data (2020).

To complement the results of the teachers' self-reported data, observation was conducted using pedagogical content knowledge indicators. From the observations, it was proven that the teachers effectively blend pedagogy and content during teaching $(\mathrm{M}=3.24$, $\mathrm{SD}=.263$ ). Also, teachers use real life examples and analogies to present the content of Social Studies to the diverse interest and ability of pupils $(\mathrm{M}=3.11, \mathrm{SD}=.234)$. More so, it was evident from the observation that teachers demonstrate effective use of content and 
pedagogy knowledge during teaching $(\mathrm{M}=3.07, \mathrm{SD}=.343)$. Further, it was found from the observation that to a large extent, teachers address pupils' difficulties they face during instruction by representing and formulating the content that makes it comprehensible. $(\mathrm{M}=3.03, \mathrm{SD}=.233)$. The results from the observation gave some evidence to believe that teachers were somehow competent when it comes to using different assessment techniques in assessing pupils' understanding of content taught $(\mathrm{M}=2.56, \mathrm{SD}=.924)$. This is largely because traditional assessment and oral assessment were mostly used. The finding of this research question based on the teachers' self-reported data and the observation is that Social Studies teachers possess adequate PCK.

From the literature, the researchers' results share similar views with other researchers. For example, Messina \& Tabone (2012) conducted a study on integrating technology into instructional practices focusing on teacher's knowledge and reported that teachers scored high on Pedagogical Content Knowledge $(\mathrm{M}=4.28 ; \mathrm{SD}=.679)$ indicating that teachers feel able to choose effective teaching and learning approaches to guide pupils reasoning, to plan lessons that stimulate pupils' interest and to guide pupils to link the subject-matter with their own reality. Again, the findings of this research question are partly in line with the findings of Quashigah, Eshun, \& Mensah, (2013) who reported that Social Studies teachers have adequate pedagogical content knowledge in Social Studies. Furthermore, the findings of this research question affirm the statement of the National Council for the Social Studies (NCSS, 2010) that the methods course for Social Studies teachers' preparation should focus on the "pedagogical content knowledge that deals specifically with the nature of Social Studies and with ideas, strategies and techniques for teaching Social Studies at the appropriate level" (p. 54). Again, this finding supports the statement that content knowledge alone could not ensure the effectiveness of teaching (Barker, 2007; Kahan, Cooper \& Bethea, 2003). However, the finding of the study contradicts that of Hristovitch \& Mitchltree (2004) who reported that teachers failed to develop the operational conception; that is, in relating the theoretical aspect of the subject that they teach with practical terms (learning theories). They also have difficulty in connecting new ideas with what they already know, employing hands-on activities and sequencing of topics. Also, the finding of Sarkim (2004) that the teachers exhibited low level of understanding and implementation of PCK and that all the teachers had problems in their conceptual understanding and their teaching was mainly done by the lecture method is apparently refuted by this finding.

Research Question Two: What are the assessment practices of Junior High School Social Studies teachers in the West Akim Municipality?

Table 5 presents statistical analysis of Social Studies teachers' response to research question two. The respondents expressed their views on the level at which they agree or disagree to statements on Social Studies teachers' assessment practices. Assessment is an inevitable part of classroom activities, therefore teachers' ability to effectively assess their pupils will have great impact on teaching and learning of Social Studies. 
Table 5: Descriptive Statistics of Teachers Assessment Practices $(n=77)$

\begin{tabular}{|c|c|c|c|c|c|c|c|c|}
\hline \multirow{3}{*}{ Assessment Practices } & \multirow{2}{*}{\begin{tabular}{|c|} 
M \\
Stat.
\end{tabular}} & \multirow{2}{*}{$\begin{array}{l}\text { SD } \\
\text { Stat. }\end{array}$} & \multirow{2}{*}{\begin{tabular}{|l|} 
Min. \\
Stat.
\end{tabular}} & \multirow{2}{*}{$\begin{array}{l}\text { Max. } \\
\text { Stat. }\end{array}$} & \multicolumn{2}{|c|}{ Kurtosis } & \multirow{2}{*}{ MR } & \multirow{2}{*}{ Remarks } \\
\hline & & & & & Stat. & Std. E & & \\
\hline & \multicolumn{8}{|c|}{ Criterion $/$ Test Value $=2.50$} \\
\hline $\begin{array}{l}\text { I give prompt feedback to pupils after } \\
\text { any assessment activity }\end{array}$ & 3.79 & .358 & 1.00 & 4.00 & .212 & .344 & 1st & GAP \\
\hline $\begin{array}{l}\text { My assessment tasks enhance the } \\
\text { development of pupils' conceptual } \\
\text { understanding/problem solving. }\end{array}$ & 3.72 & .293 & 1.00 & 4.00 & .323 & .461 & 2nd & GAP \\
\hline $\begin{array}{l}\text { My Social Studies assessment tasks put } \\
\text { emphasis on pupils' ability to apply } \\
\text { relevant knowledge acquired in solving } \\
\text { problems. }\end{array}$ & 3.59 & .934 & 1.00 & 4.00 & .766 & .393 & $3 r d$ & GAP \\
\hline $\begin{array}{l}\text { I provide adequate time for pupils } \\
\text { when they do any assessment activities. }\end{array}$ & 3.57 & .348 & 1.00 & 4.00 & .398 & .344 & 4th & GAP \\
\hline I assess pupils holistically. & 3.53 & .345 & 1.00 & 4.00 & .395 & .204 & 5 th & GAP \\
\hline $\begin{array}{l}\text { I use multiple assessment techniques to } \\
\text { assess my pupils. }\end{array}$ & 3.52 & .328 & 1.00 & 4.00 & .391 & .354 & 6th & GAP \\
\hline $\begin{array}{l}\text { I evaluate my assessment items against } \\
\text { the objectives of my lesson. }\end{array}$ & 3.42 & .233 & 1.00 & 4.00 & .303 & .461 & 7 th & GAP \\
\hline $\begin{array}{l}\text { My Social Studies assessment tasks } \\
\text { stress on pupils' skill of placing value } \\
\text { judgment on issues. }\end{array}$ & 3.37 & .372 & 1.00 & 4.00 & .515 & .424 & 8th & GAP \\
\hline $\begin{array}{l}\text { I mostly use test items provided in } \\
\text { textbook and past examination } \\
\text { questions to assess my pupils. }\end{array}$ & 3.29 & .729 & 1.00 & 4.00 & .453 & .383 & 9th & GAP \\
\hline $\begin{array}{l}\text { I use traditional assessment method } \\
\text { (pen/pencil and paper) to assess my } \\
\text { pupils. }\end{array}$ & 3.27 & .359 & 1.00 & 4.00 & .473 & .323 & 10th & GAP \\
\hline $\begin{array}{l}\text { I use alternative assessment methods } \\
\text { (Portfolio, Peer assessment, Checklist, } \\
\text { Project based evaluation etc.) to assess } \\
\text { my pupils. }\end{array}$ & 3.24 & .342 & 1.00 & 4.00 & .535 & .224 & 11 th & GAP \\
\hline $\begin{array}{l}\text { I cater for individual differences in the } \\
\text { classroom during assessment. }\end{array}$ & 3.23 & .434 & 1.00 & 4.00 & .336 & .302 & 12 th & GAP \\
\hline $\begin{array}{l}\text { I include assessment items that enable } \\
\text { me check out my pupils' reasoning } \\
\text { ability. }\end{array}$ & 3.17 & .428 & 1.00 & 4.00 & .348 & .384 & 13th & GAP \\
\hline $\begin{array}{l}\text { I balance the items of assessment } \\
\text { depending on the time I spent on a } \\
\text { particular lesson, its level of } \\
\text { significance and coverage. }\end{array}$ & 3.13 & .438 & 1.00 & 4.00 & .192 & .234 & 14th & GAP \\
\hline Most of my questions are recall of facts. & 2.61 & .354 & 1.00 & 4.00 & .295 & .324 & 15th & AAP \\
\hline Mean of means & 3.36 & .419 & & & & & & \\
\hline $\begin{array}{l}\text { Key: } \text { MR }^{*}=\text { Mean Ranking; Stat. }{ }^{*}=\text { Stati } \\
\text { Std.E } E^{*}=\text { Standard Error; Min. }{ }^{*}=\text { Min } \\
\text { Assessment Practice }\end{array}$ & $\mathrm{M}^{*}$ & $=\mathrm{Me}$ & $\mathrm{SD}^{*}$ & $\tan$ & $\mathrm{D}$ & tion & $\mathrm{ax}^{*}=$ & aximum; \\
\hline
\end{tabular}

Source: Field Data (2020). 
The results of teachers' self-reported data in table 5 show that teachers gave prompt feedback to pupils after any assessment activity $(\mathrm{M}=3.79, \mathrm{SD}=.358, \mathrm{KS}=.212$, Std. $\mathrm{E}=.344, \mathrm{n}=77)$. The data from Table 5 also revealed that most of the teacher's assessment tasks enhance the development of pupils' conceptual understanding/problem solving. Mean and standard deviation of $(\mathrm{M}=3.72, \mathrm{SD}=.293 \mathrm{KS}=.323$, Std. $\mathrm{E}=.461, \mathrm{n}=77)$ was realised from teachers' response. In another related investigation, it was found that most of the Social Studies teachers' assessment tasks put emphasis on pupils' ability to apply relevant knowledge acquired in solving problems $(\mathrm{M}=3.59, \mathrm{SD}=934, \mathrm{KS}=.766$, Std. $\mathrm{E}=.393$, $\mathrm{n}=77)$. Table 5 further gave ample evidence to believe that teachers provide adequate time for pupils when they do any assessment activity. The mean and standard deviation of $(\mathrm{M}=3.57, \mathrm{SD}=348, \mathrm{KS}=.398$, Std. $\mathrm{E}=.344, \mathrm{n}=77)$ confirmed that fact. Elicited responses again showed that Social Studies teachers assess their pupils holistically. A mean and standard deviation of $(\mathrm{M}=3.53, \mathrm{SD}=348, \mathrm{KS}=.395$, Std. $\mathrm{E}=.204, \mathrm{n}=77)$ gave statistical indication. This implies teachers agreed that their assessment practices covered all the domains of learning. It was further asserted by most of the teachers that they use multiple assessment techniques to assess their pupils $(\mathrm{M}=3.52, \mathrm{SD}=328, \mathrm{KS}=.391$, Std. $\mathrm{E}=.354, \mathrm{n}=77)$. In another evidence, it was found that most teachers evaluate their assessment items against the objectives of their lesson. The recorded mean and standard deviation of $(\mathrm{M}=3.42, \mathrm{SD}=.233$, $\mathrm{KS}=.303$, Std. $\mathrm{E}=.461, \mathrm{n}=77$ ) confirm the teachers' position. This is very important to attain the goal of each lesson in the textbook. Since every lesson has its own objectives, setting items against these objectives is the implication of good practice of assessment.

Again, from Table 5, the data revealed that Social Studies teachers' assessment tasks stress on pupils' skill of placing value judgment on issues $(\mathrm{M}=3.37, \mathrm{SD}=.372$, $\mathrm{KS}=.515$, Std. $\mathrm{E}=.424, \mathrm{n}=77$ ). Teachers' self-reported data in table 5 further proved that teachers mostly use test items provided in textbook and past examination questions to assess their pupils. This obtained a mean and standard deviation of $(\mathrm{M}=3.29, \mathrm{SD}=.729$, $\mathrm{KS}=.453$, Std. $\mathrm{E}=.383, \mathrm{n}=77$ ). The teachers further confirmed that they mostly use traditional assessment method (pen/pencil and paper) to assess their pupils. This was established after the mean and standard deviation of $(\mathrm{M}=3.27, \mathrm{SD}=.359, \mathrm{KS}=.473$, Std. $\mathrm{E}=.323, \mathrm{n}=77$ ) was realised from their responses. Aside the above, teachers' self-reported data in table 5 gave ample evidence that a substantial number of teachers use alternative assessment methods (portfolio, peer assessment, checklist, project-based evaluation etc.) to assess their pupils. The statistical result $(\mathrm{M}=3.24, \mathrm{SD}=.342, \mathrm{KS}=.473$, Std. $\mathrm{E}=.505, \mathrm{n}=77)$ confirms the respondents' response. Another factor was that most teachers cater for individual differences in the classroom during assessment $(\mathrm{M}=3.23, \mathrm{SD}=.434, \mathrm{KS}=.336$, Std. $E=.302, n=77)$. The results further indicated that majority of the teachers $(M=3.17$, $\mathrm{SD}=.428, \mathrm{KS}=.348$, Std. $\mathrm{E}=.384, \mathrm{n}=77$ ) include assessment items that enable them check pupils' reasoning ability. Again, it was realised that considerable number of the teachers asserted that they balance their assessment items depending on the time they spent on a particular lesson, its level of significance and coverage. This recorded a mean and standard deviation of $(\mathrm{M}=3.13, \mathrm{SD}=.438, \mathrm{KS}=.192$, Std. $\mathrm{E}=.234, \mathrm{n}=77)$. 
Finally, the teachers self-reported data in table 5 showed that on the average, teachers agreed that most of their questions are recall of facts. Statistically, the result $(\mathrm{M}=2.61, \mathrm{SD}=.354, \mathrm{KS}=.295$, Std. $\mathrm{E}=.324, \mathrm{n}=77)$ confirmed their response. A group mean and standard deviation of $(\mathrm{M}=3.36, \mathrm{SD}=.419)$ gave sufficient indication that Social Studies teachers assessment practices are good.

To validate the findings obtained from teachers self-reported data with respect to their assessment practices, the researchers personally observed some indicators that measures Social Studies teachers' assessment practices. The result from the observation is presented in Table 6 .

Table 6: Observation Checklist Results on Assessment Practice $(\mathrm{n}=10)$

\begin{tabular}{|l|c|c|c|c|}
\hline Statements & M & SD & Rank & Remarks \\
\hline $\begin{array}{l}\text { Most of the questions asked were recalling } \\
\text { of facts. }\end{array}$ & 3.74 & .263 & 1 st & $\begin{array}{c}\text { Very } \\
\text { Competent }\end{array}$ \\
\hline $\begin{array}{l}\text { Traditional assessment method was used } \\
\text { to assess pupils' understanding of concept. }\end{array}$ & 3.70 & .213 & 2 nd & $\begin{array}{c}\text { Very } \\
\text { Competent }\end{array}$ \\
\hline $\begin{array}{l}\text { Teacher uses textbook provided items and } \\
\text { past questions to assess pupils. }\end{array}$ & 2.92 & .230 & 4 th & $\begin{array}{c}\text { Very } \\
\text { Competent }\end{array}$ \\
\hline $\begin{array}{l}\text { Teacher gives pupils immediate feedback } \\
\text { when they need directions to proceed. }\end{array}$ & 2.73 & .723 & 5 th & Competent \\
\hline $\begin{array}{l}\text { Assessment task(s) measure(s) the objective(s) } \\
\text { of the lesson. }\end{array}$ & 2.65 & .279 & 6 th & $\begin{array}{c}\text { Somehow } \\
\text { Competent }\end{array}$ \\
\hline $\begin{array}{l}\text { Teacher provides adequate time for } \\
\text { assessment. }\end{array}$ & 2.14 & .623 & 7 th & $\begin{array}{c}\text { Not } \\
\text { competent }\end{array}$ \\
\hline $\begin{array}{l}\text { Teacher assessment task covers the three } \\
\text { domains. }\end{array}$ & 1.64 & .253 & 8 th & $\begin{array}{c}\text { Not } \\
\text { Competent }\end{array}$ \\
\hline $\begin{array}{l}\text { Teacher uses multiple assessment techniques } \\
\text { to assess pupils. }\end{array}$ & 1.33 & .283 & 9 th & $\begin{array}{c}\text { Not } \\
\text { Competent }\end{array}$ \\
\hline $\begin{array}{l}\text { Alternative assessment methods were used to } \\
\text { assess pupils' application of content taught. }\end{array}$ & 2.70 & .322 & & \\
\hline Means of means/SD & & \\
\hline
\end{tabular}

Source: Field data (2020)

Result from the observation shows a mean value of (M=3.74, $\mathrm{SD}=.263)$ confirming that most of the questions asked by Social Studies teachers in the West Akim Municipality were recalling of facts learnt. The finding of this study agrees with those of Quashigah, Eshun, and Mensah, (2013) that most teachers highlighted cognitive questioning dealing with recalling of fact learnt. It was again observed that majority of the teachers $(M=3.70$, $\mathrm{SD}=.213$ ) use traditional assessment method to assess pupils' understanding of concept. An indication that pen/pencil and paper type of assessment is mostly practiced by Social Studies teachers within West Akim Municipality. This is influenced by the policy demands of summative assessments, which require use of traditional practices in large measure. Further observation showed that most of the Social Studies teachers $(M=3.49$, $\mathrm{SD}=.263$ ) use textbook provided items and past questions to assess pupils. The results from the observation further showed that Social Studies teachers did not lay emphasis on 
all the educational domains when assessing pupils. From the data collected from the questionnaire, although a mean and standard deviation of $(\mathrm{M}=3.53, \mathrm{SD}=348)$ gave clear indication that majority of the teachers confirmed to assess pupils holistically, it proved contrary during the observation conducted in the classroom. The recorded mean and standard deviation of $(\mathrm{M}=2.14, \mathrm{SD}=.623)$ for the classroom observation gave evidence to that fact. This finding is in line with that of Quashigah, Eshun, and Mensah, (2013) which concluded that what teachers stated and said they assessed by using all the three domains (cognitive, affective and psychomotor domains) were contradicted. It is therefore clear that the result conflicts the statements of the CRDD (2007) which stated that all the domains must be used for effective teaching, learning and assessment in Social Studies. Majority of the respondents who answered items on the questionnaire agreed that they use multiple assessment techniques to assess pupils as well as using alternative assessment methods. These recorded means and standard deviation of $(\mathrm{M}=3.52, \mathrm{SD}=328)$ and $(\mathrm{M}=3.24, \mathrm{SD}=.342)$ respectively affirming the teacher's assertion. However, results for the classroom observation contradicted the teachers self-reported data. The recorded means and standard deviation of $(\mathrm{M}=1.64, \mathrm{SD}=.253)$ and $(\mathrm{M}=1.33, \mathrm{SD}=.283)$ respectively for the classroom observation gave evidence that teachers were really lacking as it was found that the teachers were not competent in these areas. A group mean and standard deviation of $(M=2.70, S D=.322)$ is an indication that the assessment practices of the Social Studies teachers can be rated as within average. The finding for research question two (2) is that Social Studies teachers mostly practice traditional assessment method (pen/pencil and paper) to determine the extent to which pupils demonstrate desired learning outcome.

\subsection{Analysis of the Research Hypothesis}

$\mathrm{H}_{0}$ : There is no statistically significant relationship between the pedagogical content knowledge of Social Studies teachers and their assessment practices at the Junior High School level in the West Akim Municipality.

$\mathrm{H}_{1}$ : There is a statistically significant relationship between the pedagogical content knowledge of Social Studies teachers and their assessment practices at the Junior High School level in the West Akim Municipality.

It is evident in the literature that a relationship exists between Social Studies teachers pedagogical content knowledge and their assessment practices. This propelled the researchers to test for the significant relationship between Social Studies teachers' pedagogical content knowledge and their assessment practices at the Junior High School level in the West Akim Municipality. To achieve this, the Pearson Product Moment Correlation Co-efficient (PPMCC) was used for the analysis. In the analysis, correlation (r) was used to determine the degree and the direction of the relationship between the variables (Pedagogical Content Knowledge-PCK and Assessment Practices-AP). The correlation was tested @ 0.05 level of confidence. To obtain the scores for the Pedagogical Content Knowledge and Assessment Practices, all the items measuring these constructs on the questionnaire were computed to form a single item on the SPSS software (version, 
25.0). In performing the Pearson Product Moment Correlation Co-efficient (PPMCC) analysis, homoscedasticity assumption was checked. Figure 1 presents the results of the normality assumption.

Figure 1: Homoscedasticity Normality Assumption

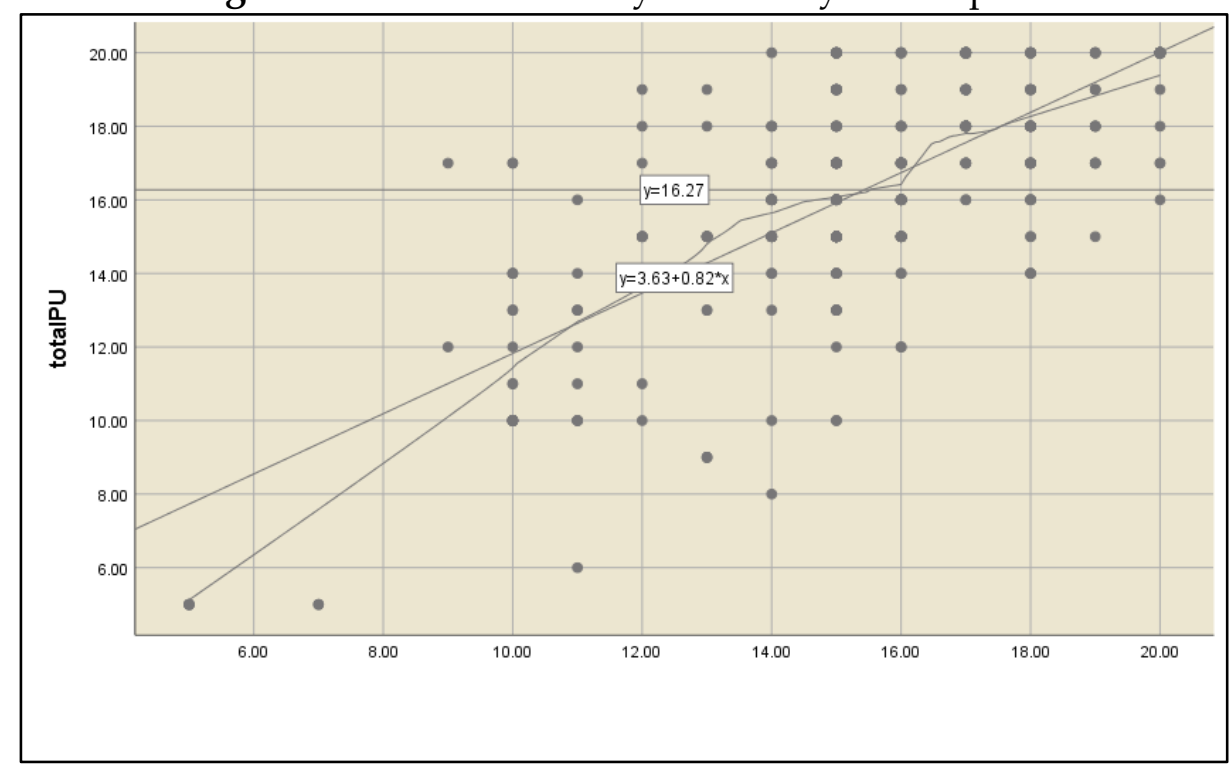

Source: Field Data, 2020

In Figure 1, the movement of the variable along the diagonal line in the figure shows that the data were assumed normal and as such Pearson Product Moment Correlation Co-efficient (PPMCC) could be performed. Table 7 presents the means, standard deviation and the correlation coefficients between the variables for the hypothesis.

Table 7: Correlation Coefficients Results between PCK and Assessment Practices $(n=77)$

\begin{tabular}{|c|c|c|c|c|}
\hline \multicolumn{2}{|c|}{$\begin{array}{l}\text { Correlated Variables } \\
\left(\text { PCK }^{*} \mathrm{AP}\right)\end{array}$} & \multirow{2}{*}{$\begin{array}{c}\text { M/SD } \\
12.23 / .335\end{array}$} & \multirow{2}{*}{$\begin{array}{c}\begin{array}{c}\text { Pedagogical } \\
\text { Content Knowledge } \\
\text { (PCK) }\end{array} \\
1\end{array}$} & \multirow{2}{*}{$\begin{array}{c}\begin{array}{c}\text { Assessment } \\
\text { Practices } \\
\text { (AP) }\end{array} \\
.819^{*}\end{array}$} \\
\hline Pedagogical & Pearson Correlation & & & \\
\hline Content & Sig. (2-tailed) & & & $.000^{*}$ (sig., $\left.p<0.05\right)$ \\
\hline $\begin{array}{l}\text { Knowledge } \\
\text { (PCK) }\end{array}$ & N-sample & & 77 & 77 \\
\hline \multirow{3}{*}{$\begin{array}{l}\text { Assessment } \\
\text { Practices } \\
\text { (AP) }\end{array}$} & Pearson Correlation & $12.23 / .335$ & $.819^{*}$ & 1 \\
\hline & Sig. (2-tailed) & & $.000^{*}$ (sig., $\mathrm{p}<0.05$ ) & \\
\hline & N-sample & & 77 & 77 \\
\hline
\end{tabular}

The results in Table 7 show that there was a statistically significant positive correlation between PCK and Assessment Practices among JHS Social Studies Teachers in the West Akim Municipality $\left(r=.819^{* *}, \mathrm{M}=12.23, \mathrm{SD}=.335\right.$, sig. $=.000^{* *} \mathrm{p}<0.05, \mathrm{CI}=95 \%, \mathrm{n}=77,2-$ tailed). The two variables share a variance of .819 (84\%). This implies that the variables predict themselves $84 \%$. The results mean that PCK influences the ability of Social Studies 
teachers at the JHS level in the West Akim Municipality to effectively teach and assess their pupils in the classroom. This confirms the postulation of Akinlaye (2002) that "what teachers' believe to be good instructional content to teach and appropriate methods to use in the classroom as well as assessment strategies to use are greatly influenced by teachers' pedagogical content knowledge of the subject" (p.4). It also substantiates Quashigah, Eshun and Mensah (2013) finding that the pedagogical content knowledge of Social Studies teachers does influence the way they assess their lessons. The finding is also in line with the National Council for the Social Studies (NCSS, 2004) assertion that teaching Social Studies powerfully and authentically begins with a teacher's deep knowledge and understanding of the subject and its unique goals. The general finding on teacher's assessment practices is that Social Studies teachers practice traditional assessment method (pen/pencil and paper) in their pursuit to determine the extent to which pupils demonstrate desired learning outcome. This is influenced by the policy demands of summative assessments, which require the use of traditional practices in large measure.

\section{Conclusion and Recommendations}

Based on the findings of the study, the following conclusions are drawn.

1) Social Studies teachers within the West Akim Municipality possessed the requisite pedagogical content knowledge to help pupils get understanding of facts and concepts taught in Social Studies.

2) Social Studies teachers practice traditional assessment method (pen/pencil and paper) to determine the extent to which pupils demonstrate desired learning outcome.

3) There is a gap between theory and practice with respect to the prescriptions of the profile dimensions as majority of Social Studies teachers' assessment items are emphasised on the cognitive domain at the expense of the other domains. Simply having knowledge without practice is not sufficient to attain the objectives of Social Studies.

4) Lastly, it is concluded that Social Studies teacher's pedagogical content knowledge has a direct bearing on their ability to effectively assess their pupils in the classroom.

The following recommendations have been made regarding the result of the study for policy and practice.

1) In order to sustain, maintain and improve Social Studies teachers 'content pedagogical knowledge, it is recommended that Ghana Education Service (GES), National Social Studies Association (NaSSA) and Social Studies curriculum specialists/experts should frequently organise seminars, workshops and conferences on Social Studies content and pedagogy so as to develop Social Studies teachers' knowledge of effective unification of pedagogy and content during instructional periods. 
2) Social Studies teachers in the JHS should study and practice fully the stipulation of the profile dimension of the subject as this will help to achieve the desired goals and objectives of the subject.

3) Social Studies teachers within the West Akim Municipality should make use of alternative assessment techniques such as project-based evaluation, observation checklist, peer assessment, portfolio assessment etc. These other techniques will help cater for affective and psychomotor assessments which will help develop pupils' attitudes and values.

\section{Conflict of Interest Statement}

The authors declare no conflicts of interests.

\section{About the Authors}

Robert Andrews Ghanney is a senior lecturer in Social Studies at the Department of Basic Education of University of Education, Winneba, Ghana.

Mr. Edward Boafo Adjei is a holder of MPhil degree in Basic Education with a specialization in Social Studies.

\section{References}

Archambault, L. \& Crippen, K. (2009). Examining TPACK among K-12 online distance educators in the United States. Contemporary Issues in Technology and Teacher Education, 9(1), 71-88

Akinlaye, F. A. (2002). Social Studies methods for teachers (2 ${ }^{\text {nd }}$ ed.). Pumark Educational Publishers.

Akhtar, S. (2008). The implementation of education for citizenship in Scotland: Recommendation of approaches for effective practice. Improving Schools, 11(5), 3348.

Barker, D. D. (2007). Teachers' knowledge of algebraic reasoning: Its organisation for instruction (Unpublished Doctoral Dissertation). University of Missouri, Columbia.

Boyd, C. O. (2001). Phenomenology the method. In P. L. Munhall, (Ed.), Nursing research: A qualitative perspective ( $3^{\text {rd }}$ ed.) Jones and Bartllett.

Bordoh, A., Eshun, I., Kofie, S., Bassaw, K. T., \& Kwarteng, P. (2015). Social Studies teachers' content knowledge in Senior High Schools in the Sekondi-Takoradi Metropolis in the Western Region of Ghana. American Journal of Social Science Research, 3(1), 169-117.

Cohen, L. (2000). Research methods in education ( $3^{\text {rd }}$ ed.) Routledge.

Corbin, J., \& Strauss, A. (2008). Basics of qualitative research: Techniques and procedures for developing grounded theory ( $3^{\text {rd }}$ ed.). Sage 
Creswell, J. W. (2009). Research design: Qualitative, quantitative, and mixed methods approaches ( $3^{\text {rd }}$ ed.). Sage Publications, Inc.

CRDD, (2007). Social Studies teaching syllabus for Junior High Schools. Ministry of Education.

Danielson, C. (2007). Enhancing professional practice: A Framework for teaching (2 ${ }^{\text {nd }}$ ed.). ASCD

De Vellis, R. F. (1991). Scale development: theory and applications. Sage.

Denzin, N. \& Lincoln, Y. S. (2000). The discipline and practice of qualitative research. In Denzin, N.K. \& Lincoln, Y.S., (Eds.), Handbook of qualitative research. Sage.

Eshun, I., Naya, D. Z., Brew, E. \& Bordoh, A. (2019a). Implications of teachers' knowledge of Social Studies profile dimensions in teaching and learning in Senior High Schools. Journal of Social Sciences and Humanities, 5(3), 209-221

Ernest, P. (1991) Constructivism, the psychology of learning, and the nature of Mathematics: Some Critical Issues, in Proceedings of PME-15 (Italy), 2, 25-32.

Eshun, I \& Mensah, M. F. (2013). Domain of educational objectives Social Studies teachers' questions emphasise in Senior High Schools in Ghana. Journal of Education and Practice, 4(4), 187-196.

Fraenkel, J. R., \& Wallen, N. E. (2003). How to design and evaluate research in education (5 ${ }^{\text {th }}$ ed.). McGraw-Hill.

Gay, L. R., Mills, G. E., \& Airasian, P. (2009). Educational research: Competencies for analysis and applications ( $9^{\text {th }}$ ed.). Pearson Education.

George, B., \& Mallery, P. (2011). SPSS for windows step by step: A simple guide and reference: Pearson

Gray, D. E. (2013). Doing research in the real world. London: Sage.

Hammil, M. (1987). Transforming student assessment. Phi Delta Kappan, 79(1), 34-40.

Harris, J., Mishra, P., \& Koehler, M. (2009). Teachers' technological pedagogical content knowledge and learning activity types: Curriculum-based technology integration reframed. Journal of Research on Technology in Education, 41(4), 393-416.

Hristovitch, S. \& Mitcheltree, M. (2004). Explaining middle school teachers' pedagogical content knowledge of fractions and decimals. Paper presented at the annual meeting of the North American Chapter of the International Group for the Psychology of Mathematics Education, Retrieved 21st, October, 2019 from http://www.allacademic.com

Kahan, J., Cooper, D., \& Bethea, K. (2003). The role of Mathematics teachers' content knowledge in their teaching: A framework for research applied to a study of student teachers. Journal of Mathematics Teacher Education, 6, 223-252.

Kathy, C. (2000). How do we assess learning in Integrated Science in bachelor of Science in education? Making sense of Integrated Science: A guide for high schools. Colorado Springs Koehler, M. J., \& Mishra, P. (2008). Introducing TPACK. Handbook of technological pedagogical content knowledge (TPACK) for educators. New York: American association of colleges for teacher education. 
. Koehler, M. J., \& Mishra, P. (2008). Introducing TPACK. Handbook of technological pedagogical content knowledge (TPACK) for educators. American association of colleges for teacher education.

Linn, R. L. \& Gronlund, N. E. (1995). Measurement and assessment in teaching (7th ed.) Prentice-Hall.

Messina, L., \& Tabone, S. (2012). Integrating technology into instructional practices focusing on teacher knowledge. Journal of Social and Behavioural Sciences 46,10151027.

National Council for the Social Studies. (2004). Program standards for the initial preparation of Social Studies teachers. National Council for the Social Studies

Nind, M. (2020). A new application for the content of pedagogical content knowledge: teaching advanced social science research methods. Oxford Review of Education. 46(2), 185-201

Odetoyinbo, B. B. (2004). Evaluation of the Nigerian Integrated Science programme in Junior Secondary Schools in Oyo State. Unpublished Ph.D. Thesis, University of Ibadan, Ibadan.

Parkay, F. W. \& Stanford, B. (2014). Becoming a teacher ( $8^{\text {th }}$ ed.). Translated into Mandarin by China Renmin University Press and Pearson Education Asia, Ltd.

Phye, G. D. (2007). Empirical methods for evaluating education: British Journal of Education Technology, 38(2), 373-384.

Quartey, S. M. (2011). Lecture notes on nature and philosophy of Social Studies. Orit Egwa Ltd. Quashigah, A. Y., Eshun, I., \& Mensah, M. F. (2013). Influences of the pedagogical content knowledge of graduate Social Studies teachers on questions they set in Senior High Schools in Ghana. Research on Humanities and Social Sciences 3(6), 76-86.

Rust, C. (2002) The impact of assessment on student learning: How can the research literature practically help to inform the development of departmental assessment strategies and learner-centered assessment practices? Active Learning in Higher Education, 3(2), 145-158.

Sarkim, T. (2004). Investigating Secondary School Physics teachers' pedagogical content knowledge: A Case study. Journal of Graduate Students, 5(1), 82-96.

Schram, T. M. (2003). Conceptualizing qualitative inquiry. Merrill Prentice-Hall.

Shulman, L. (1987). Knowledge and teaching. Harvard Educational Review, 57(1), 1-21.

Shulman, L. S. (1986). Those who understand: Knowledge growth in teaching. Educational Research, 15(2), 4 -14.

Tantrarungroj, P. \& Suwannatthachote, P. (2012). Enhancing pre-Service teacher's selfefficacy and technological pedagogical content knowledge in designing digital media with self-regulated learning instructional support in online project-based learning. Creative Education, 3, 77-81.

Voogt, J., Fisser, P., Tondeur, J., \& Van-Braak, E. (2012). Teachers' assessment of TPACK: where are we and what is needed? Koehler, M. \& Mishra, P. (Eds.), Proceedings of society for information technology $\mathcal{E}$ teacher education international conference. Chesapeake, VA: AACE. 
Wahyuni, D. (2012). The research design maze: Understanding paradigms, cases, methods and methodologies. Sage.

Creative Commons licensing terms

Author(s) will retain the copyright of their published articles agreeing that a Creative Commons Attribution 4.0 International License (CC BY 4.0) terms will be applied to their work. Under the terms of this license, no permission is required from the author(s) or publisher for members of the community to copy, distribute, transmit or adapt the article content, providing a proper, prominent and unambiguous attribution to the authors in a manner that makes clear that the materials are being reused under permission of a Creative Commons License. Views, opinions and conclusions expressed in this research article are views, opinions and conclusions of the author(s). Open Access Publishing Group and European Journal of Education Studies shall not be responsible or answerable for any loss, damage or liability caused in relation to/arising out of conflicts of interest, copyright violations and inappropriate or inaccurate use of any kind content related or integrated into the research work. All the published works are meeting the Open Access Publishing requirements and can be freely accessed, shared, modified, distributed and used in educational, commercial and non-commercial purposes under a Creative Commons Attribution 4.0 International License (CC BY 4.0). 